Disubmit 21 April 2019

Diterima 30 Juni 2019

\title{
HUBUNGAN PENGGUNAAN ALAT PELINDUNG DIRI (APD) DENGAN KETERPAPARAN LOGAM TIMBAL (PB) PADA PETUGAS TANDA PEMBAYARAN RETRIBUSI (TPR) DINAS PERHUBUNGAN DI TERMINAL RAJABASA BANDAR LAMPUNG
}

\author{
THE RELATIONSHIP OF THE USE OF SELF- \\ PROTECTIVE EQUIPMENT (EXTENSION) WITH \\ EXPOSURE OF TIMBAL (PB) IN RETRIBUTION \\ SIGN OFFICERS OF DEPARTMENT OF \\ TRANSPORTATION IN RAJABASA TERMINAL \\ BANDAR LAMPUNG
}

\author{
1, Nova Nurwinda Sari, Lentera Nunyai Putri ${ }^{2}$, Annisa Agata ${ }^{3}$. \\ Program Studi Keperawatan, Fakultas Kesehatan, Universitas Mitra Indonesia. \\ Program Studi Kesehatan Masyarakat, Fakultas Kesehatan, Universitas Mitra Indonesia. \\ Program Studi Keperawatan, Fakultas Kesehatan, Universitas Mitra Indonesia
}

\begin{abstract}
ABSTRAK
Transportasi berkontribusi lebih dari setengah penyebab polusi udara, terutama dari kendaraan yang menggunakan bensin sebagai bahan bakar. Petugas tanda pembayaran retribusi (TPR) Dinas Perhubungan di terminal Rajabasa Bandar Lampung memiliki risiko terkena paparan logam timbal $(\mathrm{Pb})$. Dampak paparan logam timbal $(\mathrm{Pb})$ dapat menyerang sistem saraf, sistem ginjal, sistem reproduksi, sistem endokrin, dan jantung. Jenis penelitian kuantitatif, metode analitik observasional dengan desain cross sectional. Populasi berjumlah 36 petugas retribusi pembayaran (TPR) Dinas Perhubungan Terminal Rajabasa Bandar Lampung. Tekhnik Sampel menggunakan total populasi. Instrumen yang digunakan mikroskop binokular dan metode pengukuran Persiapan Skrining Darah dengan penemuan sel penetapan basofilik. Analisis data menggunakan uji univariat dan bivariat Fisher Exact. Berdasarkan hasil uji univariat terdapat 25 responden $(69,4 \%)$ positif terpapar logam timbal $(\mathrm{Pb})$ dan uji statistik diperoleh Fisher Exact ( $\mathrm{p}$ value $>0,05)$ yang berarti bahwa tidak ada hubungan antara penggunaan alat pelindung diri (APD) dengan keterpaparan logam timbal $(\mathrm{Pb})$ pada petugas pembayaran retribusi (TPR) Dinas perhubungan di terminal Rajabasa Bandar Lampung.
\end{abstract}

Kata kunci : Timbal (Pb), Alat Pelindung Diri (APD)

\section{ABSTRACT}

Transportation contributes more than half of the causes of air pollution, especially from vehicles that use gasoline as fuel. The Transportation Department's levy payment 
(TPR) duty officer at Rajabasa Bandar Lampung terminal has a risk of lead metal exposure $(\mathrm{Pb})$. The impact of lead metal exposure (Pb) can attack the nervous system, kidney system, reproductive system, endocrine system, and heart. This type of quantitative research is an observational analytic method with cross sectional design. The population amounted to 36 officers of payment levy (TPR) of the Department of Transportation at the terminal Rajabasa Bandar Lampung. The sample is the total population of blood samples of officers. Instruments used binocular microscope and measurement method of Blood Screen Preparation with the discovery of basophilic stippling cells. Data analysis used univariate and bivariate test Fisher Exact. Based on univariate test result 25 respondents $(69,4 \%)$ exposed positively exposed to lead metal $(\mathrm{Pb})$ and statistical test obtained Fisher Exact ( $p$ value $>0,05)$ meaning that there is not relation between usage of personal protective equipment (APD) with exposure of metal lead $(P b)$ to the officer of payment levy (TPR) of the transportation agency at the terminal of Rajabasa Bandar Lampung.

Keywords : Lead (Pb), Personal Protective Equipment (PPE)

\author{
Alamat Korespondensi : Universitas Mitra Indonesia \\ Email : nova_sari@umitra.ac.id
}

\title{
PENDAHULUAN
}

Transportasi ternyata memberikan kontribusi lebih dari separuh penyebab polusi udara, terutama dari kendaraan yang menggunakan bensin sebagai bahan bakar. Semakin bertambahnya jumlah kendaraan bermotor yang dipergunakan di jalan raya, maka gas buang yang dikeluarkan pun semakin meningkat. Beberapa polutan yang berasal dari gas buang kendaraan bermotor antara lain $\mathrm{CO}, \mathrm{HC}, \mathrm{NO}_{2}$, $\mathrm{SO}_{2}, \mathrm{~Pb}$ dan partikulat debu (Sukoco, 2009).

Bahan aditive yang biasa dimasukkan ke dalam bahan bakar kendaraan bermotor pada umumnya terdiri dari $62 \%$ tetraetil-Pb, $18 \%$ etilendikhlorida, $18 \%$ etilenbromida dan sekitar $2 \%$ campuran tambahan dari bahan-bahan yang lain. Jumlah senyawa $\mathrm{Pb}$ yang jauh lebih besar dibandingkan dengan senyawa-senyawa lain dan tidak terbakar musnahnya $\mathrm{Pb}$ dalam peristiwa pembakaran pada mesin menyebabkan jumlah $\mathrm{Pb}$ yang dibuang ke udara melalui asap buangan kendaraan menjadi sangat tinggi (Palar,2008).

Menurut Environment Project Agency, Emisi Pb dari gas buangan tetap akan menimbulkan pencemaran udara dimanapun kendaraan itu berada, tahapannya adalah sebagai berikut : sebanyak $10 \%$ akan mencemari lokasi dalam radius kurang dari $100 \mathrm{~m}, 5 \%$ akan mencemari lokasi dalam radius $20 \mathrm{~km}$, dan $35 \%$ lainnya terbawa atmosfer dalam jarak yang cukup jauh. Sekitar 25\% logam berat Timbal $(\mathrm{Pb})$ tetap berada dalam mesin dan 75\% lainnya akan mencemari udara sebagai asap knalpot (Gustina, 2012).

Proses masuknya $\mathrm{Pb}$ kedalam tubuh dapat melalui beberapa jalur, yaitu melalui makanan dan minuman, udara, dan perembesan atau penetrasi pada selaput atau lapisan kulit. Organ-organ tubuh yang banyak menjadi sasaran dari peristiwa keracunan logam $\mathrm{Pb}$ adalah sistem syaraf, sistem ginjal, sistem reproduksi, sistem endokrin dan jantung. Setiap bagian yang diserang oleh racun $\mathrm{Pb}$ akan memperlihatkan efek yang berbeda-beda (Palar, 2008). 
Sebagian besar dari $\mathrm{Pb}$ yang terhirup pada saat bernafas akan masuk ke dalam pembuluh darah dan paru-paru. Logam $\mathrm{Pb}$ yang masuk ke paru-paru melalui peristiwa pernafasan akan terserap dan akan berikatan dengan darah paru-paru untuk kemudian diedarkan ke seluruh jaringan dan organ tubuh. Lebih dari $90 \%$ logam $\mathrm{Pb}$ yang terserap oleh darah berikatan dengan sel darah merah (erytrocyt) (Palar, 2008).

Penyerapan asap kendaraan bermotor dalam jangka waktu yang lama dan tanpa penggunaan alat pelindung diri (APD) diduga penyebab utama keterpaparan logam timbal $(\mathrm{Pb})$ yang menyebabkan toksisitas dalam tubuh petugas tanda pembayaran retribusi (TPR).

Tujuan penelitian ini adalah untuk mengetahui hubungan penggunaan alat pelindung diri (apd) dengan keterpaparan logam timbal ( $\mathrm{pb}$ ) pada petugas tanda pembayaran retribusi (tpr) dinas perhubungan di terminal rajabasa Bandar lampung.

\section{METODE PENELITIAN}

Jenis penelitian ini merupakan penelitian kuantitatif. Desain penelitian adalah analitik observasional dengan rancangan cross sectional yaitu penelitian yang menggali bagaimana dan mengapa fenomena kesehatan itu terjadi, yang dititik beratkan pada analisis korelasi, yakni mempelajari pengaruh variabel yaitu observasi atau pengumpulan data dilakukan pada satu waktu (Notoatmodjo, 2012).

Penelitian ini dilakukan di terminal Rajabasa Bandar Lampung dan dilaksanakan pada tanggal 07 Juli s/d 23 Juli 2017.

Populasi pada penelitian ini adalah petugas tanda pembayaran retribusi (TPR) Dinas Perhubungan di terminal Rajabasa Bandar Lampung dengan jumlah 36 orang. Tekhnik pengambilan sampel yang digunakan adalah total populasi yang berjumlah 36 orang.

Instrumen yang digunakan untuk variabel Penggunaan alat pelindung diri (APD) adalah Lembar checlist penggunaan APD pada petugas, sedangkan untuk variabel Keterpaparan logam timbal $(\mathrm{Pb})$, peneliti melakukan pemeriksaan Sediaan Apus Darah (SAD) dengan menggunakan mikroskop.Uji analisis data yang dilakukan adalah uji analisis univariat dan bivariat.

\section{HASIL DAN DISKUSI}

\section{HASIL}

Tabel 1

Distribusi Frekuensi Menurut Keterpaparan Logam Timbal (Pb)

\begin{tabular}{lcc}
\hline $\begin{array}{c}\text { Keterpaparan Logam } \\
\text { Timbal }(\mathrm{Pb})\end{array}$ & $\begin{array}{c}\text { Frekuensi } \\
(\mathrm{n})\end{array}$ & $\begin{array}{c}\text { Persentase } \\
(\%)\end{array}$ \\
\hline Positif & 25 & 69,4 \\
Negatif & 11 & 30,6 \\
\hline Jumlah & 36 & 100.0 \\
\hline
\end{tabular}

Data diolah Tahun 2017. 
Berdasarkan Tabel 1, dari total 36 responden, sebanyak 25 responden $(69,4 \%)$ dinyatakan positif terpapar logam timbal $(\mathrm{Pb})$ atau terdapat titik basofil dalam darah.

Tabel 2

Distribusi Frekuensi Menurut Penggunaan Alat Pelindung Diri (APD)

\begin{tabular}{lcc}
\hline \multicolumn{1}{c}{ Penggunaan APD } & $\begin{array}{c}\text { Frekuensi } \\
(\mathrm{n})\end{array}$ & $\begin{array}{c}\text { Persentase } \\
(\%)\end{array}$ \\
\hline Tidak Menggunakan & 35 & 97,2 \\
Menggunakan & 1 & 2,8 \\
\hline Jumlah & 36 & 100.0 \\
\hline
\end{tabular}

Sumber: Data diolah Tahun 2017

Berdasarkan tabel 2, dari total 36 responden,sebanyak 35 responden $(97,2 \%)$ tidak menggunakan Alat Pelindung Diri (APD).

Tabel 3

Distribusi Frekuensi Menurut Penggunaan Alat Pelindung Diri (APD)

\begin{tabular}{|c|c|c|c|c|c|c|c|}
\hline \multirow[t]{3}{*}{$\begin{array}{l}\text { Penggunaa } \\
\text { n APD }\end{array}$} & \multicolumn{4}{|c|}{$\begin{array}{c}\text { Keterpaparan Logam } \\
\text { Timbal }(\mathrm{Pb})\end{array}$} & \multirow{2}{*}{\multicolumn{2}{|c|}{ Total }} & \multirow[t]{3}{*}{$\begin{array}{c}P- \\
\text { Value }\end{array}$} \\
\hline & \multicolumn{2}{|c|}{ Positif } & \multicolumn{2}{|c|}{ Negatif } & & & \\
\hline & $\mathrm{n}$ & $\%$ & $\mathrm{n}$ & $\%$ & $\mathrm{n}$ & $\%$ & \\
\hline $\begin{array}{l}\text { Tidak } \\
\text { Menggunak } \\
\text { an }\end{array}$ & 25 & 71,4 & 10 & 28,6 & 35 & 100,0 & 0,306 \\
\hline $\begin{array}{l}\text { Menggunak } \\
\text { an }\end{array}$ & 1 & 100 & 0 & 0 & 1 & 100,0 & \\
\hline Total & 26 & 72,2 & 10 & 27,8 & 36 & 100,0 & \\
\hline
\end{tabular}

Berdasarkan tabel 3, dari jumlah total 35 responden yang tidak menggunakan alat pelindung diri (APD) sebanyak 25 responden (71,4\%) dinyatakan positif terpapar logam timbal $(\mathrm{Pb})$. Sedangkan dari total 1 responden yang menggunakan alat pelindung diri (APD) sebanyak 1 orang (100\%) dinyatakan positif terpapar logam timbal $(\mathrm{Pb})$.

Hasil uji statistic diperoleh $p$-value $=0,306$ ( $p$-value $>0,05)$, yang berarti tidak ada hubungan antara penggunaan alat pelindung diri (APD) dengan keterpaparan logam timbal $(\mathrm{Pb})$ pada Petugas Tanda Pembayaran Retribusi (TPR) Dinas Perhubungan di terminal Rajabasa Bandar Lampung tahun 2017.

\section{DISKUSI HASIL}

Berdasarkan hasil penelitian, didapatkan hasil bahwa responden yang terpapar logam timbal $(\mathrm{Pb})$ sebanyak 25 orang dengan presentase 69,4\%, dansebanyak 11 orang responden tidak terpapar logam $(\mathrm{Pb})$ dengan presentase $30,6 \%$.

Titik basofil adalah kelainan pada eritrosit dengann terdapatnya titik biru yang difus dalam eritrosit yang dikenal sebagai titik basofil. Titik basofil (basophilic stippling) dapat terjadi karena terganggunya pemecahan RNA karena terhambatnya kerja enzim pirimidin 5' nukleotidase, yang menyebabkan akumulasi 
RNA yang terdenaturasi dalam eritrosit, kemudian RNA tersebut memberikan gambaran yang disebut titik basofil (basophilic stippling) pada pewarnaan biasa (Hoffbrand, 2005).

Pada sediaan apus darah yang normal semua sel menunjukkan volume, bentuk, dan warna yang sama. Basophilic stippling tampak sebagai granula kecil, berbentuk bulat, dan berwarna biru gelap. Granula biasanya terdistribusi merata keseluruh sel dan membutuhkan ketelitian untuk mendeteksinya. Basophilic stippling kadang berupa butiran kasar yang dikaitkan dengan tingkat keparahannya secara klinis (Kiswari, 2014).

Pemeriksaan titik basofil dapat digunakan sebagai pertanda adanya keracunan timbal dan juga merupakan pemeriksaan laboratorium yang sederhana, mudah dan cepat dibandingkan dengan pemeriksaan timbal yang lainnya. Untuk melakukan pemeriksaan sel-sel darah pada apusan darah tepi secara tepat, maka perlu dilakukan pewarnaan (Kiswari, 2014).

Hasil penelitian yang dilakukan oleh Nur Latifah Syakbanah (2015) tentang Hubungan kadar $\mathrm{Pb}$ udara dan karakteristik responden terhadap kadar $\mathrm{Pb}$ darah tukang becak di Gresik, didapatkan hasil bahwa 100\% responden memiliki kadar $\mathrm{Pb}$ darah normal bagi dewasa menurut WHO yakni $<10 \mu \mathrm{g} / \mathrm{dl}$.

Berdasarkan ditemukannya titik basophil dalam darah petugas dapat disimpulkan sebagian besar petugas tanda pembayaran retribusi (TPR) Dinas Perhubungan di terminal Rajabsa Bandar Lampung yang menjadi responden dalam penelitian ini. Hal ini menunjukkan risiko terjadinya keterpaparan logam timbal $(\mathrm{Pb})$.

Berdasarkan hasil penelitian, didapatkan hasil bahwa dari total 36 responden, sebanyak 35 responden $(97,2 \%)$ tidak menggunakan Alat Pelindung Diri (APD).

Alat Pelindung Diri selanjutnya disingkat APD adalah suatu alat yang mempunyai kemampuan untuk melindungi seseorang yang fungsinya mengisolasi sebagian atau seluruh tubuh dari potensi bahaya di tempat kerja. (Permenakertrans PER.08/MEN/VII/2010, Pasal 1 ayat 1).

APD dalam Pasal 3 ayat 1 meliputi : Pelindung kepala, Pelindung mata dan muka, Pelindung telinga, Pelindung pernapasan beserta perlengkapannya, Pelindung tangandan Pelindung kaki. Sedangkan pada pasal 3 ayat 2, Selain APD sebagaimana dimaksud pada ayat (1), yang termasuk APD adalah pakaian pelindung, alat pelindung jatuh perorangan; dan/atau pelampung. APD wajib digunakan di tempat kerja di mana terdapat atau menyebar suhu, kelembaban, debu, kotoran, api, asap, gas, hembusan angin, cuaca, sinar atau radiasi, suara atau getaran (Pasal 4 ayat 1 poin $\mathrm{m}$ ).

Menurut Daryanto (2007), terdapat 2 Jenis Alat Pelindung Pernapasan yakni masker dan respirator. Masker berguna untuk melindungi debu atau partikelpartikel yang lebih besar yang masuk dalam pernapasan dan dapat terbuat dari kain dengan ukuran pori-pori tertentu. Macam dan penggunaan masker adalah masker penyaring debu, masker berhidung dan masker bertabung.

Sedangkan Respirator berguna untuk melindungi pernapasan dari debu, kabut, uap, logam, asap dan gas. Menurut Buntarto (2015), macam dan penggunaan respirator antara lain : Respirator penyedia udara, Air line respirator, Air hose respirator, Self contained breathing approach (SCBA)dan Half-mask Twin Filter. 
Penelitian yang dilakukan oleh Fauziah Noviyanti (2012) tentang gambaran kadar timbal dalam Urine pada pegawai Stasiun pengisian bahan bakar umum (SPBU) di kota Makasar didapatkan hasil bahwa seluruh responden tidak memakai Alat Pelindung Diri berupa masker dan sarung tangan. Para responden ini semuanya hanya memakai topi / penutup kepala saja. Dapat disimpulkan bahwa semua responden pada kedua SPBU yang diteliti tidak memakai Alat Pelindung Diri atau $100 \%$ responden tidak memenuhi kriteria syarat penelitian.

Berdasarkan analisis uji Bivariat dengan uji statistik (Fisher Exact) dapat disimpulkan bahwa tidak terdapat hubungan antara penggunaan penggunaan alat pelindung diri (APD) dengan keterpaparan logam timbal $(\mathrm{Pb})$. Hal ini dapat ditunjukkan dengan $p$-value $(0,306)>\alpha(0,05)$.

Bahaya dan dampak kesehatan yang ditimbulkan kadar $\mathrm{Pb}$ darah dalam batas rendah juga dapat menyebabkan gejala keracunan akut maupun kronis dalam jangka panjang. Terutama bagi para pekerja di pinggir jalan yang sering terpapar polusi timbal $(\mathrm{Pb})$. Beberapa faktor yang dapat mempengaruhi tingkat keterpaparan timbal dalam tubuh manusia antara lain faktor karakteristik individu yaitu usia, jenis kelamin, kebiasaan merokok, status gizi dan kesehatan, serta kelainan genetik (Siwiendrayanti dkk, 2016).

Penelitian yang dilakukan oleh Sam Sam Ekabada, dkk (2013) tentang Faktor Yang Berhubungan Dengan Kadar Timbal $(\mathrm{Pb})$ Dalam Darah Sopir Koperasi Angkutan Kota Mahasiswa Dan Umum (Kakmu) Trayek 05 Kota Makassar didapatkan hasil bahwa ada hubungan masa kerja, lama kerja, lama paparan dan kebiasaan merokok dengan kadar timbal dalam darah pada Sopir Koperasi Angkutan Kota Mahasiswa dan Umum (KAKMU) trayek 05 Kota Makassar tahun 2013.

Sedangkan penelitian yang dilakukan oleh Friska Ayu, dkk (2016) tentang Hubungan Karakteristik Pekerjaan Dengan Kadar Timbal Dalam Darah (Pbb) Pada Operator Spbu Di Kecamatan Tamalanrea Kota Makassar Tahun 2016 didapatkan hasil bahwa terdapat hubungan yang signifikan antara masa kerja $(0,000)$, durasi pengisian $(0,005)$, jumlah kendaraan yang dilayani $(0,023)$ dan jumlah bbm yang terjual $(0,003)$ dengan kadar timbal dalam darah.

Berdasarkan hasil penelitian, menurut pandangan peneliti bahwa para pekerja yang sering terpapar polusi timbal $(\mathrm{Pb})$ seperti petugas TPR, polisi lalu lintas, tukang becak, petugas SPBU dll agar selalu menggunakan alat pelindung diri terutama untuk alat pernafasan seperti masker atau respirator serta penggunaan pakaian yang menutup anggota tubuh (pakaian lengan panjang) dan sarung tangan. Hal ini dilakukan salah satunya untuk mengurangi keterpaparan logam timbal dalam darah $(\mathrm{Pb})$.

\section{SIMPULAN DAN SARAN}

Dari total 36 responden, sebanyak 25 responden $(69,4 \%)$ dinyatakan positif terpapar logam timbal $(\mathrm{Pb})$ atau terdapat titik basofil dalam darah.

Dari total 36 responden, sebanyak 35 responden $(97,2 \%)$ tidak menggunakan Alat Pelindung Diri (APD).

Tidak ada hubungan antara penggunaan alat pelindung diri (APD) dengan keterpaparan logam timbal $(\mathrm{Pb})$ pada Petugas Tanda Pembayaran Retribusi (TPR) 
Dinas Perhubungan di terminal Rajabasa Bandar Lampung tahun 2017 dengan $p$ value $=0,306$ ( $p$-value $>\alpha=0,05)$.

Diharapkan kepada para pekerja yang sering bekerja di pinggir jalan seperti petugas TPR, polisi lalu lintas, tukang becak, petugas SPBU dll agar selalu menggunakan alat pelindung diri terutama untuk alat pernafasan seperti masker atau respirator serta penggunaan pakaian yang menutup anggota tubuh (pakaian lengan panjang) dan sarung tangan. Hal ini dilakukan salah satunya untuk mengurangi keterpaparan logam timbal dalam darah $(\mathrm{Pb})$.

\section{DAFTAR PUSTAKA}

1. Astika, Dewi Sri. 2008. Pemeriksaan Titik Basofil Dalam Darah Pedagang Asongan Di Terminal Rajabasa Bandar Lampung.Karya Tulis Ilmiah, Politeknik Kesehatan Tanjungkarang Jurusan Analis Kesehatan, Lampung.

2. Bada, Eka Sam Sam, dkk,2014, Tentang Faktor Yang Berhubungan Dengan Kadar Timbal (Pb) Dalam Darah Sopir Koperasi Angkutan Kota Mahasiswa Dan Umum (Kakmu) Trayek $05 \quad$ Kota Makassar.Https://core.ac.uk/download/pdf/25495749.pdf.Diakses pada tanggal 04 Maret 2017.

3. Buntarto. 2015.Panduan Praktis Keselamatan dan Kesehatan Kerja untuk Industri, Pustaka Baru Press :Yogyakarta.

4. Dewi,Putri Puspita, dkk. 2015.Faktor-Faktor Yang Berhubungan Dengan Kadar Plumbum (Pb) Dalam Darah Pada Polisi Lalu Lintas Di Kota KendariTahun 2015. Http: //ojs.uho. ac.id/index. php/ JIMKESMAS / article/view/668.Diakses pada tanggal 04 Maret 2017.

5. Gandasoebrata, R. 2011.Penuntun Laboratorium Klinik, Dian Rakyat, Jakarta.

6. Gustina,Dessy. 2012. "Pencemaran Logam Berat Timbal (Pb) di Udara", Jurnal Berita Dirgantara Vol.13, No. 3, halaman 95-101, Bandung, bulan September 2012, http:// Jurnal. Lapan . go .id/index.php/berita_dirgantara larticle/.../1553. Diakses pada tanggal 04 Maret 2017.

7. Hastono, Priyo Sutanto. 2007. Analisis Data Kesehatan. Fakultas Kesehatan Masyarakat Universitas Indonesia. : Jakarta

8. Hoffbrand Moss, P.A.H, A.V, Petit, J.E. 2005.Kapita Selekta Hematologi Edisi 4, diterjemahkan oleh Lyana Setiawan, EGC: Jakarta.

9. Irianto, Kus. 2005.Struktur dan Fungsi Tubuh Manusia untuk Paramedis, CV. Yrama Widya : Bandung.

10. Ir. Soedirman, Dr. dr. Suma'murPrawirakusumah, M. Sc., SpOK. 2014.Kesehatan Kerja Dalam Perspektif Hiperkes dan Keselamatan Kerja, PT.Gelora Aksara Pratama, Erlangga :Jakarta.

11. Kementerian Tenaga Kerja dan Transmigrasi RI. 2010.Peraturan Menteri Tenaga Kerja dan Transmigrasi RI Nomor: 08/ Men/VII/ 2010 Tentang Alat Pelindung Diri, Menteri Tenker-trans : Jakarta.

12. Kiswari, Rukman. 2014. Hematologi dan Transfusi. Erlangga : Jakarta.

13. Mathias, Freund. 2009.Atlas Hematologi Heckner: Praktikum Hematologi dengan Mikroskop, Edisi11, diterjemahkan oleh Frans Dany, EGC:Jakarta.

14. Manopo,Apriyanti. dkk. 2015. Tentang Hubungan Masa Kerja Dan Penggunaan Alat Pelindung Diri (Respirator) Dengan Kapasitas Vital Paru 
Pada Petugas Pemadam Kebakaran Di Dinas Pemadam Kebakaran Kota Manado.

Https://ejournal.Unstrat.ac.id/index.php/pharmacon/article/.../981Diaksespad a tanggal 04 Maret 2017.

15. Nasir, Abd dkk. 2011. Buku Ajar Metodologi Penelitian Kesehatan, Nuha Medika : Yogyakarta.

16. Notoatmodjo, S. 2012. Metodologi Penelitian Kesehatan, PT. RinekaCipta: Jakarta.

17. Palar,Haryando. 2008.Pencemaran dan Toksikologi Logam Berat, Rineka Cipta: Jakarta.

18. Puspita Sari, Mayang. 2016. Hubungan Karakteristik Individu Dan Pemakaian Alat Pelindung Diri (Apd) Dengan Kadar Timbal (Pb) Dalam Darah Pada Pekerja Pengecatan Di Industri Karoseri. Skripsi, Fakultas Kesehatan MasyarakatUniversitas Diponegoro.

19. Rahmania, Puji. 2015. Gambaran Titik Basofil Pada Pedagang Di Terminal Kota Metro.Karya Tulis Ilmiah, Politeknik Kesehatan Tanjungkarang Jurusan Analis Kesehatan, Lampung.

20. Sacher, Ronald A. 2004.Tinjauan Klinis Hasil Pemeriksaan Laboratorium Edisi 11, diterjemahkan oleh Brahm U. Pendit, EGC: Jakarta.

21. Sartono, 2002, Racun dan Keracunan, Widya Medika : Jakarta. Singer Freres $>$ equipments industiels professionnels de protection. www. singer.fr. Diakses 04 Maret 2017.

22. Siwiendrayanti, A, dkk. 2016. Buku Ajar Toksikologi.Cipta Prima Nusantara :Semarang.

23. Suciani, Sri. 2007.Kadar Timbal dalam Darah Polisi Lalu Lintas dan Hubungannya dengan Kadar Hemoglobin, Tesis Sarjana, Program Pascasarjana Universitas Diponegoro,Semarang. Http://eprints.undip.ac.id /15877 /1/ Sri_Suciani.Diakses pada tanggal 04 Maret 2017.

24. Sukoco, AZ. 2009.Pengendalian Polusi Kendaraan, Alfabeta : Bandung.

25. Suma'mur, 1995, Higiene Perusahaan dan Kesehatan Kerja, PT. Toko Gunung Agung, Jakarta.

26. Tarwoto, Ratna Aryani, Wartonah. 2009. Anatomi dan Fisiologi untuk Mahasiswa Keperawatan, CV. Trans Info Media : Jakarta.

27. Terminal Rajabasa-Wikipedia bahasa Indonesia, ensiklopedia bebas https://id.wikipedia.org/wiki/Terminal_Rajabasa, diakses pada tanggal 04 Maret 2017. 